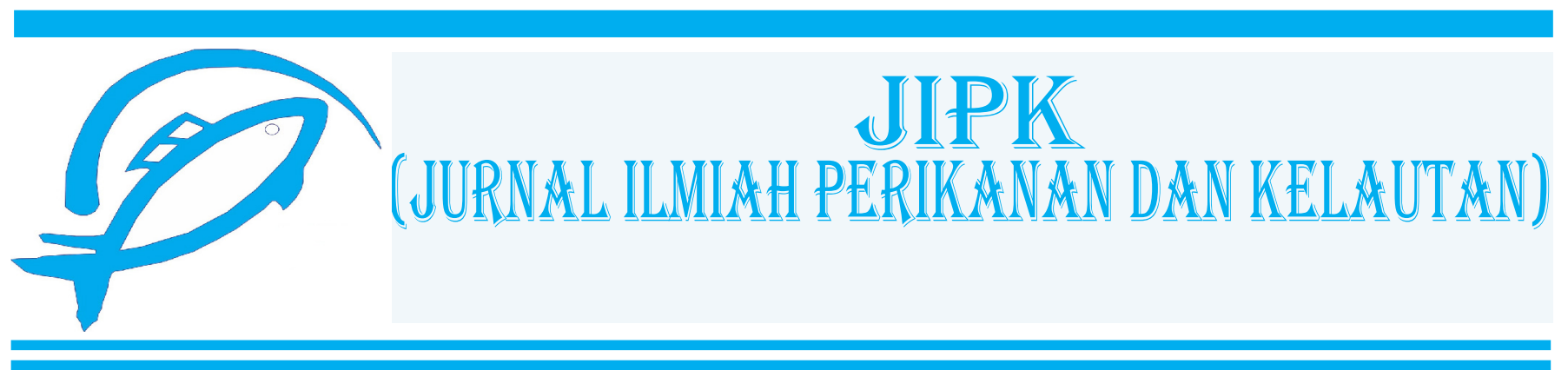

Short Communication

\title{
Bioaccumulation of some heavy metals in Red mullet (Mullus barbatus), and common Pandora (Pagellus erythrinus) from Zliten coast, Libya
}

\author{
Ragab Farag Al-Kazaghly ${ }^{*}$ (D), Mohamed Hamid ${ }^{1}$, and Keri Alhadi Ighwela ${ }^{2}$ \\ ${ }^{1}$ Department of Zoology, Faculty of Science, Al - Asmarya University, Zliten. Libya \\ ${ }^{2}$ Department of Biology, Faculty of Education, Al - Asmarya University, Zliten. Libya
}

\section{OPEN ACCESS}

\section{ARTICLE INFO}

Received: September 25, 2020

Accepted: January 05, 2021

Published: April 03, 2021

*) Corresponding author:

E-mail:keri_gwallah@yahoo.com

Keywords:

Heavy Metals

Mullus barbatus

Pagellus erythrinus

Zliten Coast

This is an open access article under the CC BY-NC-ND license (http://creativecommons.org/licenses/by-nc-nd/4.0/)

\begin{abstract}
This study aimed to determine the heavy metals concentration such as copper $(\mathrm{Cu})$, zinc $(\mathrm{Zn})$, lead $(\mathrm{Pb})$, cadmium $(\mathrm{Cd})$, and mercury $(\mathrm{Hg})$ in the liver, gills, gonad, and muscles of red mullet (Mullus barbatus) and Common pandora ( $\mathrm{Pa}$ gellus erythrinus) collected in Zliten Coast, Libya. The levels of heavy metals were determined by using an Atomic Absorption Spectrophotometer (AAS). The results showed that the concentration of heavy metals in the sampled fishes was less than the permissible limits for human consumption. In addition, the bioaccumulation for $\mathrm{Cu}, \mathrm{Pb}, \mathrm{Cd}$, and $\mathrm{Hg}$ by both fish species went higher from liver to gills, gonads, muscles respectively, while $\mathrm{Zn}$ follows the sequence from gonads, liver, gills, muscles respectively. Therefore, the conclusion of this study was concentrations of heavy metals in the muscle tissue were within the acceptable limits for human health according to FAO and WHO.
\end{abstract}

Cite this as: Al-Kazaghly, R. F., Hamid, M., \& Ighwela, K. A. (2021). Bioaccumulation of some Heavy Metals in Red mullet (Mullus barbatus) and Common pandora (Pagellus erythrinus) in Zliten Coast, Libya. Jurnal Ilmiah Perikanan dan Kelautan, 13(1):81-86. http://doi.org/10.20473/jipk.v13i1.22037 


\section{Introduction}

Seafood has essential amino acids, fatty acids, protein, carbohydrates, vitamins, and minerals. Among kinds of seafood, fishes are widely consumed by people because they have high protein content, low saturated fat, and also omega fatty acids which function to support good health (Ikem and Egiebor, 2005). Fish production in Libya is growing up, and fish consumption by Libyan people is increasing due to its nutritional value and cheapest price. Moreover, the Mediterranean Sea is the main source of production.

The Mediterranean Sea is a semi-enclosed sea which covers 2.5 million $\mathrm{km}^{2}$. Human activities such as oil exploration, exploitation, and transportation in the region surrounding the Mediterranean Sea produce a strong environmental impact. In addition, it is also adversely affected by discharges of domestic sewage, industrial, and agricultural wastes. All of these have produced a high concentration polluted environmental of Sea which often reach the maximum global levels (Meadows, 1992) and is compounded by the very slow exchange in Mediterranean water (El-Moselhy and Hamed, 2006). The effective pollutants of heavy metals are considered as the most important pollutants of the aquatic environment because of their toxicity, long persistence, bioaccumulation, and non-biodegradable properties in the food chain (Zyadah and Chouikhi, 1999; Uysal et al., 2008).

Heavy metals such as copper and zinc are essential metals which play animportant rolein abiologicalsystem, whereas mercury, lead, and cadmium are non-essential metals as they are toxic and very harmful elements even at low concentration when having ingested over a long time period. The essential metals can also produce toxic effects when the metal intake is excessively elevated (Turkmen et al., 2008; Tuzen, 2009). Heavy metals may go into fish bodies through the body surface, the gills, or the digestive tract. The gills are regarded as the important site for direct uptake from the water, whereas the body surface is generally assumed to play a minor role in heavy metal uptake in fish. Food may also be an important source for heavy metal accumulation (Obasohan, 2007; Turkmen et al., 2008; Retief et al., 2009). Fish is the final chain of the aquatic food web and an important food source for human. Therefore, heavy metals in aquatic environments are transferred through the food chain into human. Puel et al. (1987) reported that heavy metals had the tendency to accumulate in various organs of marine organisms, especially fish, which in turn may enter into the human metabolism through consumption, causing serious health hazards.
For this reason, the determination of heavy metals levels of fish is very important for human health.

In Libya, there are most commercial on two fish species consumed which are Red mullet (Mullus Barbatus) and Common pandora (Pagellus Erythrinus). The levels of heavy metals were determined in the muscles of Red mullet (Mullus barbatus) from the eastern Aegean Sea (Turkey) by Kucuksezgin et al. (2001) and Turkmen et al. (2005) and in the muscles of Pandora (Pagellus erythrinus) from Izmir Bay (Turkey) by Kucuksezgin et al. (2002). Whereas, there is limited information on the heavy metal content of fish from the Libyan water. Therefore, the aim of this study was to determine some metal levels $(\mathrm{Cu}, \mathrm{Zn}$, $\mathrm{Pb}, \mathrm{Cd}$, and $\mathrm{Hg}$ ) in muscles, livers, gills and gonads from the more popular fish species such as Common pandora (Pagellus erythrinus) and Red mullet (Mullus barbatus) in Zliten region and to assess whether they are acceptable for human consumption. They also have commercial importance and are considered as one of the most important sources of food in the studied area (Zliten city).

\section{Materials and Methods}

\subsection{Fish Collection}

Fresh samples of two fish species were used in this study: Common pandora (Pagellus erythrinus) and Red mullet (Mullus barbatus). These species are commonly consumed by the local population in Libya.

\subsection{Methods}

Fish samples were purchased from local fishermen at Zliten harbors (Figure 1) in the same day of capture and brought to the laboratory by an icebox immediately and then frozen at $20^{\circ} \mathrm{C}$ until dissection. Ten samples from each fish species were obtained. After defrosting, total fish length and weight of the samples were measured in millimeter and gram. Furthermore, they were dissected by using stainless steel dissection instruments whilst wearing surgical gloves. The procedure used for measuring concentrations of heavy metals in tissues has been described previously by Bahnasawy et al. (2010).

In order to minimize contamination, all glassware used in the experiment were previously soaked in a soap solution, rinsed in distilled water, acid-washed in dilute $\mathrm{HCL}$, and rinsed in distilled water once again. In addition to this, the chemical used for sample dissolution was all of the analytical grade. Parts (about $1 \mathrm{~g}$ ) of muscles (epiaxial muscle which was removed from below the dorsal fin of each fish), liver, gills, and gonad were put into small Erlenmeyer flasks and dried in an oven at $105^{\circ} \mathrm{C}$ 
for about 24 hours. In order to determine the percentage of moisture for each sample, the wet and dry masses of the samples were recorded.

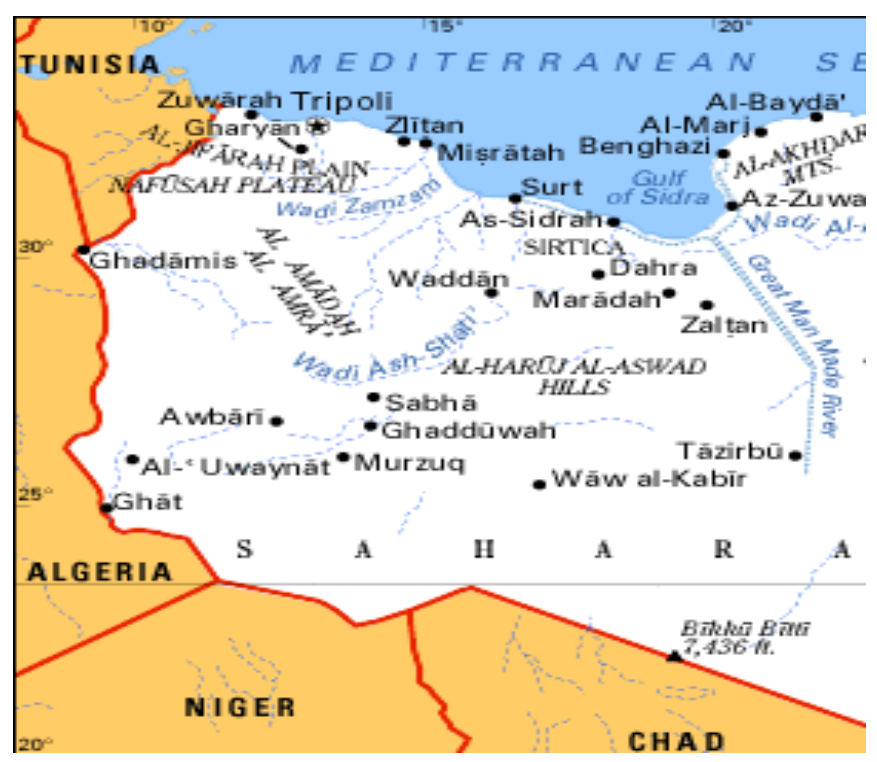

Figure 1. Map showing the sampling site (Zliten coast)

The samples were digested by adding concentrated nitric acid (65\%) and per chloric acid (70\%) in a 2:1 ratio to the dried samples. Digestion was performed on a hotplate at 200 to $250^{\circ} \mathrm{C}$ until the solution became clear. The completely digested samples were allowed to cool in room temperature, filtered through an acid-resistant $0.45 \mu \mathrm{m}$ filter paper, diluted to $25 \mathrm{ml}$ in volumetric flasks with distilled water, and stored in pre-washed glass bottles until the concentration of the metals could be determined. Concentrations of five heavy metals $(\mathrm{Cu}$, $\mathrm{Zn}, \mathrm{Pb}, \mathrm{Cd}$, and $\mathrm{Hg}$ ) were measured by using Atomic Absorption Spectrophotometer (NOV AA 400). Metal concentration in tissue was presented as $\mu \mathrm{g}$ metal/g wet weight ( $\mu \mathrm{g} / \mathrm{g}$ w.w. or ppm).

\subsection{Statistical Analysis}

Statistical analysis of the obtained data was carried out by using SPSS statistical. One way analysis of variance (ANOVA) was used to identify whether heavy metal concentrations varied significantly. A P value of less than 0.05 was considered to indicate statistical significance.

\section{Results and Discussion}

The amount of bioaccumulation of heavy metals in tissues may vary depending on the length and weight of samples (Yilmaz, 2005). The average length and weight values of the examined two fish species ( $P$. erythrinus and M. barbatus) (Table 1).

Average and standard deviations of concentrations from $\mathrm{Cu}, \mathrm{Zn}, \mathrm{Pb}, \mathrm{Cd}$, and $\mathrm{Hg}$ in the liver, gills, gonads, and muscles of the fishes examined Pagellus erythrinus and Mullus barbatus (Table 2). The contents of investigated heavy metals in fish species were found in the range of 0.18-1.89 ppm for copper, 4.907-41.492 ppm for zinc, $0.125-0.64 \mathrm{ppm}$ for lead, 0.040-0.446 ppm for cadmium, and 0.064-0.432 ppm for mercury. The general order of bioaccumulation for $\mathrm{Cu}, \mathrm{Pb}, \mathrm{Cd}$, and $\mathrm{Hg}$ by both fish species was liver, gills, gonads, and muscles went higher respectively, whereas $\mathrm{Zn}$ followed the sequence of gonads, liver, gills, and muscles went higher respectively.

$\mathrm{Cu}$ concentrations varied significantly $(\mathrm{P}<0.001)$ in both the investigated fishes and the organs of fishes (Table 2). M. barbatus contained the higher level of $\mathrm{Cu}(1.162 \mathrm{ppm})$ than P. erythrinus $(0.92 \pm 0.63 \mathrm{ppm})$. The maximum contain of $\mathrm{Cu}$ was observed in the liver of $M$. barbatus, while the minimum level was recorded in the muscles of P.erythrinus. The maximum $\mathrm{Cu}$ level permitted for fish is $20 \mu \mathrm{g} / \mathrm{g}$ for WHO (1993). Copper level in the analyzed fish samples were found to be lower than legal limits.

Zn concentrations varied significantly in both fishes and the organs of these fishes (Table 2). $M$. barbatus accumulated the highest concentration of $\mathrm{Zn}(24.950 \mathrm{ppm})$. The gonads were the major sites of $\mathrm{Zn}$ accumulation in both fish species containing the highest level of this metal, while muscles had the lowest concentration of it. The maximum zinc level permitted for fish is $100 \mu \mathrm{g} / \mathrm{g}$ according to WHO (1993). Zinc levels in the analyzed fish samples were found to be lower than the legal limits.

$\mathrm{Pb}$ concentrations varied significantly in both fishes and the organs of these fishes (Table 2). The highest $\mathrm{Pb}$ accumulation ( $0.43 \mathrm{ppm})$ was recorded in $M$. barbatus. The liver had the maximum concentration of $\mathrm{Pb}(0.64 \mathrm{ppm})$, while muscles contained the minimum concentration $(0.12 \mathrm{ppm})$ in P.erythrinus. The maximum lead level permitted for fishes is $2.0 \mu \mathrm{g} / \mathrm{g}$ according to WHO (1993). Lead levels in the analyzed fish samples were found to be lower than the legal recommended limits

$\mathrm{Cd}$ concentration varied significantly in both the fishes and the organs of these fishes (Table 2). $M$. barbatus accumulated the highest level of $\mathrm{Cd}(0.232$ ppm). The liver had the highest concentration of $\mathrm{Cd}$ ) while muscle contained the lowest level of it. The maximum cadmium level permitted for fish samples is $0.5 \mu \mathrm{g} / \mathrm{g}$ according to WHO (1993). Cadmium levels in the analyzed fish samples were found to be lower than legal limits. 
Table 1. Mean weights and lengths of the species examined in the study (Mean \pm SD).

\begin{tabular}{lcccc}
\hline \multirow{2}{*}{ Parameter } & \multicolumn{2}{c}{ Pagellus erythrinus } & \multicolumn{2}{c}{ Mullus barbatus } \\
\cline { 2 - 5 } & Range & Mean \pm SD & Range & Mean \pm SD \\
\hline Total length $(\mathrm{cm})$ & $15.5-24.5$ & $18.48 \pm 3.37$ & $14.5-18.0$ & $16.36 \pm 1.38$ \\
\hline Total weight $(\mathrm{gm})$ & $46.2-175.5$ & $88.47 \pm 48.63$ & $22.3-44.3$ & $32.16 \pm 8.07$ \\
\hline
\end{tabular}

Table 2. The mean metals concentrations $(\mathrm{ppm}) \pm$ standard division in liver, gills, gonad and muscles of investigated fishes.

\begin{tabular}{|c|c|c|c|c|}
\hline \multirow[t]{2}{*}{ Fishes } & \multicolumn{4}{|c|}{ Mean \pm SD of Copper } \\
\hline & Liver & Gills & Gonad & Total \\
\hline P. erythrinus & $1.56 \pm 0.57$ & $1.07 \pm 0.34$ & $0.85 \pm 0.41$ & $0.92 \pm 0.63$ \\
\hline \multirow[t]{3}{*}{ M. barbatus } & $1.89 \pm 0.68$ & $1.29 \pm 0.43$ & $1.19 \pm 0.40$ & $1.16 \pm 0.73$ \\
\hline & \multicolumn{4}{|c|}{ Mean \pm SD of Zinc } \\
\hline & Liver & Gills & Gonad & Total \\
\hline P. erythrinus & $14.92 \pm 2.45$ & $17.34 \pm 2.57$ & $29.18 \pm 9.81$ & $16.59 \pm 10.08$ \\
\hline \multirow[t]{3}{*}{ M. barbatus } & $25.27 \pm 4.61$ & $27.13 \pm 4.37$ & $41.49 \pm 9.11$ & $24.95 \pm 13.94$ \\
\hline & \multicolumn{4}{|c|}{ Mean \pm SD of Lead } \\
\hline & Liver & Gills & Gonad & Total \\
\hline P. erythrinus & $0.53 \pm 0.12$ & $0.47 \pm 0.25$ & $0.22 \pm 0.06$ & $0.34 \pm 0.22$ \\
\hline \multirow[t]{3}{*}{ M. barbatus } & $0.64 \pm 0.21$ & $0.50 \pm 0.09$ & $0.37 \pm 0.09$ & $0.43 \pm 0.21$ \\
\hline & \multicolumn{4}{|c|}{ Mean \pm SD of Cadmium } \\
\hline & Liver & Gills & Gonad & Total \\
\hline P. erythrinus & $0.14 \pm 0.02$ & $0.13 \pm 0.05$ & $0.09 \pm 0.03$ & $0.10 \pm 0.04$ \\
\hline \multirow[t]{3}{*}{ M. barbatus } & $0.44 \pm 0.13$ & $0.22 \pm 0.09$ & $0.19 \pm 0.05$ & $0.23 \pm 0.16$ \\
\hline & \multicolumn{4}{|c|}{ Mean \pm SD of Mercury } \\
\hline & Liver & Gills & Gonad & Total \\
\hline P. erythrinus & $0.26 \pm 0.06$ & $0.22 \pm 0.05$ & $0.14 \pm 0.02$ & $0.17 \pm 0.8$ \\
\hline M. barbatus & $0.31 \pm 0.14$ & $0.43 \pm 0.12$ & $0.28 \pm 0.12$ & $0.27 \pm 0.16$ \\
\hline
\end{tabular}

Table 3. Heavy metals concentrations in the organs of Pagellus erythrinus

\begin{tabular}{llllll}
\hline Organs & Liver & Gills & Gonad & Muscles & Total \\
\cline { 2 - 6 } Element & Mean \pm SD & Mean \pm SD & Mean \pm SD & Mean \pm SD & Mean SD \\
\hline $\mathrm{Cu}$ & $1.56 \pm 0.57$ & $1.07 \pm 0.34$ & $0.85 \pm 0.41$ & $0.18 \pm 0.06$ & $0.92 \pm 0.63$ \\
\hline $\mathrm{Zn}$ & $14.92 \pm 2.45$ & $17.34 \pm 2.57$ & $29.18 \pm 9.81$ & $4.91 \pm 0.56$ & $16.59 \pm 10.08$ \\
\hline $\mathrm{Pb}$ & $0.53 \pm 0.12$ & $0.47 \pm 0.25$ & $0.22 \pm 0.06$ & $0.12 \pm 0.03$ & $0.34 \pm 0.22$ \\
\hline $\mathrm{Cd}$ & $0.14 \pm 0.02$ & $0.13 \pm 0.05$ & $0.09 \pm 0.03$ & $0.04 \pm 0.01$ & $0.10 \pm 0.04$ \\
\hline $\mathrm{Hg}$ & $0.26 \pm 0.06$ & $0.22 \pm 0.05$ & $0.14 \pm 0.02$ & $0.06 \pm 0.01$ & $0.17 \pm 0.8$ \\
\hline
\end{tabular}


JIPK. Volume 13 No 1. April 2021 / Bioaccumulation of some heavy metals in Red mullet (Mullus barbatus), and common......

Table 4. Heavy metals concentrations in the organs of Mullus barbatus

\begin{tabular}{llllll}
\hline $\begin{array}{l}\text { Organs } \\
\text { Element }\end{array}$ & Liver & Gills & Gonad & Muscles & Total \\
\cline { 2 - 6 } & Mean \pm SD & Mean \pm SD & Mean \pm SD & Mean \pm SD & Mean SD \\
\hline $\mathrm{Cu}$ & $1.89 \pm 0.68$ & $1.29 \pm 0.43$ & $1.19 \pm 0.40$ & $0.27 \pm 0.06$ & $1.16 \pm 0.73$ \\
\hline $\mathrm{Zn}$ & $25.27 \pm 4.61$ & $27.13 \pm 4.37$ & $41.49 \pm 9.11$ & $5.90 \pm 1.92$ & $24.95 \pm 13.94$ \\
\hline $\mathrm{Pb}$ & $0.64 \pm 0.21$ & $0.50 \pm 0.09$ & $0.37 \pm 0.09$ & $0.19 \pm 0.05$ & $0.43 \pm 0.21$ \\
\hline $\mathrm{Cd}$ & $0.44 \pm 0.13$ & $0.22 \pm 0.09$ & $0.19 \pm 0.05$ & $0.06 \pm 0.05$ & $0.23 \pm 0.16$ \\
\hline $\mathrm{Hg}$ & $0.31 \pm 0.14$ & $0.43 \pm 0.12$ & $0.28 \pm 0.12$ & $0.07 \pm 0.02$ & $0.27 \pm 0.16$ \\
\hline
\end{tabular}

Table 5. Maximum permissible limits of heavy metals in fish according to international standards

\begin{tabular}{lllll}
\hline Heavy Metals & Pagellus erythrinus & Mullus barbatus & WHO (1993) & FAO (2009) \\
\hline $\mathrm{Cu}$ & $0.92 \pm 0.63$ & $1.16 \pm 0.73$ & $20 \mu \mathrm{g} / \mathrm{g}$ & 30 \\
\hline $\mathrm{Zn}$ & $16.59 \pm 10.08$ & $24.95 \pm 13.94$ & $100 \mu \mathrm{g} / \mathrm{g}$ & 30 \\
\hline $\mathrm{Pb}$ & $0.34 \pm 0.22$ & $0.43 \pm 0.21$ & $2.0 \mu \mathrm{g} / \mathrm{g}$ & 0.5 \\
\hline $\mathrm{Cd}$ & $0.10 \pm 0.04$ & $0.23 \pm 0.16$ & $0.5 \mu \mathrm{g} / \mathrm{g}$ & 1 \\
\hline $\mathrm{Hg}$ & $0.17 \pm 0.8$ & $0.27 \pm 0.16$ & $0.5 \mu \mathrm{g} / \mathrm{g}$ & 0.5 \\
\hline
\end{tabular}

Hg concentration varied significantly in both the investigated fishes and the organs of these fishes (Table 2). M. barbatus accumulated the highest level of $\mathrm{Hg}(0.27 \mathrm{ppm})$. The gills had the highest concentration of $\mathrm{Hg}$ while muscle contained the lowest level of both species. The maximum mercury level permitted for fish is $0.5 \mu \mathrm{g} / \mathrm{g}$ according to WHO (1993) and FAO (2007). Mercury and cadmium levels in the analyzed fish samples were found to be lower than legal limits.

Heavy metals concentrations in the organs of P. erythrinus and $M$. barbatus were also varied (Table $3 \& 4$ ). The distribution of metals in the fish organs took the following descending order $\mathrm{Zn}, \mathrm{Cu}, \mathrm{Pb}$, $\mathrm{Hg}, \mathrm{Cd}$ respectively. The total concentration values of $\mathrm{Cu}, \mathrm{Pb}, \mathrm{Cd}$, and $\mathrm{Hg}$ in the fish organs were detected in the following order which went higher respectively liver, gills, gonads, and muscles. The sequence of $\mathrm{Zn}$ concentration in the organs follow the order which went higher respectively gonads, gills, liver, and muscles. The gonad has been reported as a structure likely to present $\mathrm{Zn}$ high concentration due to their participation in excretion of toxic metals, fertilization, cellular division, and growth processes (Mormede and Davies, 2001; Uluturhan and Kucuksezgin, 2007).

In this study, the average concentrations of both essential and non-essential metals in the liver, gills, gonads, and muscles of each fish species showed significant variations. Statistical analysis revealed that metal concentrations were significantly different in each tissue from different fish species. The differences in the levels of accumulation in the different organs i.e., tissues of a fish could primarily be attributed to the differences in the physiological role of each organ. Regulatory ability, behavior, and feeding habits were other factors which could influence the accumulation differences in the different organs (Kotze et al., 1999). It was also reported that the differences in metal concentrations of the tissues might be a result of their capacity to induce metal-binding proteins such as metallothionein (Canli and Atli, 2003; Uysal et al., 2008).

\section{Conclusion}

In terms of food safety and based on the samples collected, the muscle tissue of all fish species might be considered suitable for human consumption, as the metal concentration levels observed were in the range of acceptable limits proposed by regulations of WHO and FAO especially the study of heavy metals.

\section{Acknowledgement}


The authors would like to thanks the laboratory staff of Hasan School especially Mr. Mohamed Abdullah Belqasm for their assistance in the laboratory experiment.

\section{Author's Contributions}

All authors discussed the results and contributed to from the start to final manuscript.

\section{Conflict of Interest} interests.

The authors declare that they have no competing

\section{References}

Bahnasawy, M., Khidr, A. A., \& Dheina, N. (2011). Assessment of Heavy Metal Concentrations in Water, Plankton, and Fish of Lake Manzala, Egypt. Turkish Journal of Zoology, 35(2):271-280.

Canli, M., \& Atli, G. (2003). The relationships between heavy metal $(\mathrm{Cd}, \mathrm{Cr}, \mathrm{Cu}, \mathrm{Fe}, \mathrm{Pd}, \mathrm{Zn})$ levels and the size of six Mediterranean fish species. Environmental pollution Journal, 121(1):129-136.

El- Moselhy, M. \& Hamed, M. (2006). Impact of landbased activities on hydrographic conditions and heavy metals in water and sediments along the Mediterranean Coast of Egypt. Egyptian Journal of Aquatic Research, 32(2):63-82.

Ikem, A., \& Egiebor, N. (2005). Assessment of trace elements in canned fishes (mackerel, tuna, salmon, sardines and herrings) marketed in Georgia and Alabama (United States of America). Journal Food Composition and Analysis, 18(8):771-787.

Kotze, P., Du Preez, H., \& Van Vuren, J. (1999). Bioaccumulation of copper and zinc in $\mathrm{O}$. mossambicus and Clarias gariepinus, from the Olifants River, Mpumalanga, South Africa. Water SA, 25 (1): 99-110.

Kucuksezgin, F., Altay, O., Uluturhan, E., \& Kontas, A. (2001). Trace metal and organ chlorine residue levels in red mullet (Mullus barbatus) from the eastern Aegean, Turkey. Water Research, 35(9):2327-2332.

Kucuksezgin, F., Uluturhan, E., Kontas, A., \& Altay, O. (2002). Trace metal concentration in edible fishes from Izmir Bay, Eastern Aegean. Marine pollution Bulletin journal, 14(8):816-832.

Meadows, P. (1992). Pollution, conservation and the Mediterranean ecosystem: A perspective view. Bulletin Marine Biological Research Centre, 9(B):270-298

Mormede, S. \& Davies, I. (2001). Heavy metal concentrations in commercial deep-sea fish from the Rockall Trough. Continental Shelf Research, 21(8-10):899-916.

Obasohan, E. E. (2007). Heavy metals concentrations in the offal, gill, muscle and liver of a freshwater mudfish (Parachanna obscura) from Ogba River, Benin city, Nigeria. African Journal of Biotechnology, 6(22):2620-2627.

Puel, D., Zsurger, N., \& Breittmayer, J. Ph. (1987). Statistical assessment of a sampling pattern for evolution of changes in $\mathrm{Hg}$ and $\mathrm{Zn}$ concentration in Patella coerulea. Bulletin Environmental Contamination and Toxicology, 38:700-706.

Retief, N-R., Avenant-Oldewage, A., \& Du Preez, H. H. (2009). Seasonal study on Bothriocephalus as indicator of metal pollution in yellow fish, South Africa. Water SA, 35(3):315-322.

Turkmen, A., Turkmen, M., Tepe, Y., \& Akyurt, I. (2005). Heavy metals in three commercially valuable fish species from Iskenderun Bay, northern east Mediterranean Sea, Turkey. Food Chemistry, 91(1):167-172.

Turkmen, M., Turkmen, A., Tepe, Y., Ates, A., \& Gokkus, K. (2008). Determination of metal concentrations in sea foods from Marmara, Aegean and Mediterranean Seas: Twelve fish species. Food Chemistry, 108(2):794-800.

Tuzen, M. (2009). Toxic and essential trace elemental contents in fish species from the Black Sea, Turkey. Food and Chemical Toxicology, 47 (8):1785-1790.

Uluturhan, E., \& Kucuksezgin, F. (2007). Heavy metal contaminants in Red Pandora (Pagellus erythrinus) tissues from the eastern Aegean Sea, Turkey. Water Research, 41(6): 1185-1192.

Uysal, K., Emre, Y., \& Kose, E. (2008). The determination of heavy metal accumulation ratios in muscle, skin, and gills of some migratory fish species by inductively coupled plasma- optical emission spectrometry (ICP-OES) in Beymelek Lagoon (Antalya/Turkey). Microchemical Journal, 90(1):67-70.

Yilmaz, A.B. (2005). Comparison of heavy metal levels of grey mullet (Mugil cephalus L.) and sea bream (Sparus aurata L.) caught in Iskenderun Bay (Turkey). Turkey Journal Veterinary and Animal Science, 29(2):257-262.

Zyadah, M. A., \& Chouikhi, A. (1999). Heavy metal accumulation in Mullus barbatus. Merluccius merluccius and Boops boops fish from the Aegean Sea, Turkey. International Journal of Food Science and Nutrition, 50(6):429-434. 